\title{
EFFECT OF LONG-TERM STRESS WITH HEAVY METALS COMBINATIONS ON GROWTH AND CHEMICAL COMPOSITION OF SOME ORNAMENTAL SHRUBS II. EFFECT ON CHEMICAL COMPOSITION Abdalla, M. Y. A. ${ }^{1}$ and A. M. A. Mahmoud ${ }^{2}$ 1- Veget. and Flor. Dept., Fac. of Agric., Mansoura Univ. 2- Botanical Gardens Res. Dept., Hort. Res. Inst., ARC, Giza, Egypt.
}

\begin{abstract}
Four separated pot experiments were carried out in the open field at the Experimental Station of Vegetable and Floriculture Department, Faculty of Agriculture, Mansoura University during of 2006/2007 and 2007/2008 seasons, as each season contained two periods of growth, to detect the effect of long-term stress with lead $(\mathrm{Pb})$, cadmium ( $\mathrm{Cd}$ ) and nickel $(\mathrm{Ni})$ added in combinations as thawing acetate salts to the soil mixture at six rates on chemical composition of six-months-old transplants of Acalypha wilkesiana Müll. Arg., Asclepias curassavica L., Dodonaea viscosa (L.) Jacq. and Tabernaemontana divaricata (L.) R. Br. ex Roem \& Schult. grown in 25-cmdiameter black polyethylene bags filled with $3 \mathrm{Kg}$ of a mixture composed of sand and loam at $1: 1(\mathrm{v} / \mathrm{v})$. The chemical analysis of the studied shrubs was conducted two times in the second season only; i.e. at the terminal of October 2007 (first growth period), as well as at the end of October 2008 (second growth period).

The obtained results indicated that chlorophylls a and b, carotenoids, total carbohydrates, N, P and $\mathrm{K}$ contents in the leaves of all studied shrubs were progressively decreased with increasing heavy metal concentrations to reach the minimum values in transplants subjected to the highest level of toxic metals with highly significant differences compared to the means of unpolluted ones in most cases of the two periods of growth. An exception was only obtained for transplants treated with the lowest level of heavy metals, as all previous constituents were slightly increased in the leaves of both Acalypha and Asclepias transplants, while in Tebernaemontana and Dodonaea transplants many of them were increased and many others were decreased. In general, prolonging the period of subjecting to the toxic metals stress caused a gradual decrement in the content of aforementioned constituents.

On the other hand, a progressive increase was noticed in the content of $\mathrm{Pb}$, $\mathrm{Cd}$ and $\mathrm{Ni}$ in the leaves and roots of the four used shrubs with elevating heavy metals concentrations. Moreover, the content of such metals was higher in the roots than in the leaves, and in the second growth period than in the first one. So, the highest content of them was observed in the roots of transplants polluted with the highest level in the second period of growth.

From the above mentioned results, it could be recommended to use Acalypha wilkesiana and Asclepias curassavica transplants to landscape areas suffering from $\mathrm{Pb}, \mathrm{Cd}$ and $\mathrm{Ni}$ pollution, as they absorbed the highest amounts of these metals under the conditions of the present study, followed by Tabernaemontana divaricata then Dodonaea viscose.
\end{abstract}

\section{INTRODUCTION}

Some of ornamental shrubs widely used for landscaping and gardening are sensitive to heavy metals toxicity. Among them may be the 
monocious shrub with attractive foliage Acalypha wilkesiana Müll. Arg., Jacob's coat (Fam. Euphorbiaceae), the fragrant annual or short-lived evergreen subshrub with glowing red-flowered umbels Asclepias curassavica L., blood flower (Fam. Asclepiadaceae), the tropical and subtropical shrub Dodonaea viscosa (L.) Jacq., hop bush (Fam. Sapindaceae) and the crepe jasmine or crepe gardenia Tabernaemontana divaricata (L.) R. Br. ex Roem \& Schult that belongs to Fam. Apocynaceae (Bailey, 1976).

The pollution with heavy metals has many deleterious effects; the most important of them is the effect on chemical composition of plant tissues. In this regard, Shahin et al. (2002) found that chlorophylls a and b content in the leaves of Salvia and Vinca transplants were reduced, while carotenoids content was increased in response to heavy metals pollution. A reduction was observed in total carbohydrates content in Salvia leaves and roots, but in Vinca transplants, it was increased in the leaves and decreased in the roots. Contents of both $\mathrm{N}$ and $\mathrm{K}$ in the leaves and roots were progressively decreased with increasing heavy metals level, while $\mathrm{Pb} \mathrm{Cd}$ and $\mathrm{Hg}$ were greatly increased. Dissanayake et al. (2002) noticed that Lantana camara and Albizzia ordoratissima nearly uptake $50 \%$ of $\mathrm{Zn}, \mathrm{Cd}, \mathrm{Ni}$ and $\mathrm{Mn}$ from the metal ion solutions, but the uptake of $\mathrm{Cr}, \mathrm{Co}, \mathrm{Cu}, \mathrm{Fe}$ and $\mathrm{Pb}$ was less than $50 \%$. Wedelia trilobata, however absorbed more than $1 \mathrm{mg} / \mathrm{dm}^{3}$ of $\mathrm{Cu}, \mathrm{Ni}$ and Fe after 72 hours of treatment, and $\mathrm{Mn}, \mathrm{Zn}, \mathrm{Pb}, \mathrm{Co}$ and $\mathrm{Cr}$ after 120 hours of treatment. In addition, Bush et al. (2003) revealed that $\mathrm{Zn}$ level in leaf tissue of Betula nigra and Ulmus parvifolia plants exceeded normal level, whereas pigments content was less due to growing in media amended with crumb rubber. Likewise, Laypheng et al. (2004) mentioned that the amounts of $\mathrm{Cd}$, $\mathrm{Cu}, \mathrm{Cr}, \mathrm{Fe}, \mathrm{Pb}$ and $\mathrm{Zn}$ in tissues of Bougainvillea spectabilis, Ixora coccinea and Heleconia taxa plants were significantly increased compared to the control when grown in polluted soil.

Similar observations were also recorded by Abbaas (2002) on Casuarina glauca, Taxodium distichum and Populus nigra; Rossini and Rautio (2004) on Duranta repens; Shahin and El-Malt (2006) on sant, oak and tipu; and Shahin et al. (2007) on stock (Matthiola incana) and Cape marigold (Dimorphotheca ecklonis).

Such trial, however aims to explore the effect of lead, cadmium and nickel combinations on chemical composition of some ornamental shrubs.

\section{MATERIALS AND METHODS}

Four independent pot experiments were carried out in the open field at the Experimental Station of Vegetable and Floriculture Department, Faculty of Agriculture, Mansoura University during 2006/2007 and 2007/2008 seasons to study the effect of long-term stress of $\mathrm{Pb}, \mathrm{Cd}$ and $\mathrm{Ni}$ in combinations at various levels on chemical composition of Jacob's coat, blood flower, hop bush and crepe jasmine transplants.

Therefore, six-months-old transplants of Jacob's coat $(55-60 \mathrm{~cm}$ long with 2 branches carrying about 15-17 leaves), blood flower (40-45 cm long with one branch carrying about 32-35 leaves), hop bush $(25-27 \mathrm{~cm}$ long with 
one branch carrying about 7-9 leaves) and crepe jasmine (43-45 cm long with 2 branches carrying about $16-18$ leaves) were planted on April, $1^{\text {st }}$ for both seasons in $25-\mathrm{cm}$-diameter black polyethylene bags (one transplant/bag) filled with $3 \mathrm{~kg}$ of a mixture of sand and loam $(1: 1 \mathrm{v} / \mathrm{v})$, which its some physical and chemical properties are shown in Table (a).

Thawing salts (acetates) of $\mathrm{Pb}, \mathrm{Cd}$ and $\mathrm{Ni}$ produced by Aldrich Chemical Co. Inc., USA, were thoroughly mixed in combinations with the used soil mixture before planting at the concentrations of $00.00 \mathrm{ppm}$ for each metal as a control, $500 \mathrm{ppm} \mathrm{Pb}+50 \mathrm{ppm} \mathrm{Cd}+25 \mathrm{ppm} \mathrm{Ni}$ for treatment number one $\left(T_{1}\right)$ and 2-, 3-, 4- and 5-fold of these concentrations for treatments number two $\left(T_{2}\right)$, three $\left(T_{3}\right)$, four $\left(T_{4}\right)$ and five $\left(T_{5}\right)$, respectively above the background levels of these metals in the used soil mixture. The bags (without drainage holes to prevent leaching of metals) were immediately irrigated after planting with $250 \mathrm{ml}$ of fresh water/bag, but thereafter the irrigation was done once every 3 days with only $200 \mathrm{ml}$ of water/bag. The transplants were not fertilized throughout the course of study, but received the usual agricultural practices recommended for such plantation (i.e. digging, weed control ... etc.). They were set out in a complete randomized design (Mead et al., 1993) for each plant with 3 replicates, as each replicate contained 6 transplants.

The experiments began in the first season on April, $1^{\text {st }} 2006$ and lasted for two growing periods till the end of October 2007, whereas for the second one, it commenced on April, $1^{\text {st }} 2007$ and lasted till the end of October 2008. However, chemical analyses were measured two times in the second season only; i.e. at the terminal of October of both 2007 and 2008 years as follows:

- Chlorophyll $\mathrm{a}, \mathrm{b}$ and carotenoids ( $\mathrm{mg} / \mathrm{g}$ fresh weight) were determined in fresh leaf samples taken from the middle parts of transplants according to the method of Moran (1982).

- In dry leaf samples, the percentages of total carbohydrates (Herbert et al., 1971), N (Pregl, 1945), $P$ (Luatanab and Olsen, 1965) and $K$ (Jackson, 1973) were assessed.

- Another dry samples from the leaves and roots were digested in nitric and perchloric acids and analyzed for $\mathrm{Pb}, \mathrm{Cd}$ and $\mathrm{Ni}(\mathrm{ppm})$ determination on a Perkin Elmer 403 atomic absorption spectrophotometer as the method described by Jackson (1973).

The data were subjected to analysis of variance and the method of L.S.D. was used to differentiate the means (Mead et al., 1993).

\section{RESULTS AND DISCUSSION}

Effect of lead $(\mathrm{Pb})$, cadmium ( $\mathrm{Cd}$ ) and nickel (Ni) combinations on chemical composition of the different shrubs:

1. Acalypha wilkesiana Müll. Arg. (Jacob's coat):

Data presented in Table (1) cleared that chlorophyll a, b and carotenoids content ( $\mathrm{mg} / \mathrm{g}$ fresh weight), as well as the percentages of total carbohydrates, N, P and $\mathrm{K}$ in the leaves of polluted transplants were 
Abdalla, M. Y. A. and A. M. A. Mahmoud

a

8698 
gradually decreased with increasing heavy metals level to reach the minimum values in both $\mathrm{T}_{4}$ and $\mathrm{T}_{5}$ treatments with significant and highly significant differences compared to the unpolluted ones during the two periods of growth, except for $\mathrm{T}_{1}$ combination, which slightly increased the content of all previous constituents with non-significant differences in the two growth periods. The only significant increment, which was achieved by $T_{1}$ treatment, was in chlorophyll b content in both growth periods. Prolonging the period of subjection to heavy metals stress caused a progressive decrement in the previously mentioned constituents, especially at the highest concentrations of toxic metals ( $T_{4}$ and $\left.T_{5}\right)$.

Table (1): Effect of heavy metals combinations on some chemical constituents of Acalypha wilkesiana Müll. Arg. leaves during the two periods of growth in the second season

\begin{tabular}{|c|c|c|c|c|c|c|c|}
\hline \multirow[t]{2}{*}{ Treatments } & $\begin{array}{c}\text { Chlorophyll } \\
\text { a } \\
\text { (mg/g f. w.) }\end{array}$ & $\begin{array}{c}\text { Chlorophyll } \\
\text { b } \\
\text { (mg/g f. w.) }\end{array}$ & $\begin{array}{c}\text { Carotenoids } \\
\text { (mg/g f. w.) }\end{array}$ & $\begin{array}{c}\text { Total } \\
\text { carbohydrates } \\
(\%)\end{array}$ & $\begin{array}{c}N \\
(\%)\end{array}$ & $\begin{array}{c}P \\
(\%)\end{array}$ & $\begin{array}{c}K \\
(\%) \\
\end{array}$ \\
\hline & \multicolumn{7}{|c|}{ First period of growth (terminal of October 2007) } \\
\hline Control & 0.475 & 0.197 & 0.407 & 63.75 & 1.84 & 0.063 & 1.36 \\
\hline $\mathrm{T}_{1}$ & 0.490 & $0.265^{*}$ & 0.446 & 66.50 & 1.92 & 0.071 & 1.48 \\
\hline $\mathbf{T}_{2}$ & 0.468 & 0.183 & 0.369 & 61.63 & 1.80 & 0.067 & 1.39 \\
\hline $\mathbf{T}_{3}$ & 0.386 & 0.159 & 0.341 & 51.80 & 1.47 & 0.052 & 1.13 \\
\hline $\mathbf{T}_{4}$ & $0.328^{* *}$ & 0.130 * & 0.336 & $43.86^{*}$ & 1.28 * & $0.043^{*}$ & $0.95 *$ \\
\hline$T_{5}$ & $0.281^{* *}$ & $0.098^{* *}$ & $0.312^{*}$ & $41.72^{* *}$ & $1.07^{*}$ & $0.037^{*}$ & $0.81^{* *}$ \\
\hline \multirow{3}{*}{$\begin{array}{r}\text { L.S.D } 5 \% \\
1 \% \\
\end{array}$} & 0.093 & 0.043 & 0.072 & 12.03 & 0.53 & 0.012 & 0.26 \\
\hline & 0.141 & 0.074 & 0.094 & 20.33 & 0.81 & 0.028 & 0.43 \\
\hline & \multicolumn{7}{|c|}{ Second period of growth (terminal of October 2008) } \\
\hline Control & 0.518 & 0.215 & 0.435 & 64.43 & 1.76 & 0.061 & 1.48 \\
\hline $\mathrm{T}_{1}$ & 0.534 & $0.283^{*}$ & 0.456 & 67.84 & 1.82 & 0.069 & 1.31 \\
\hline$T_{2}$ & 0.446 & 0.176 & 0.350 & 58.56 & 1.70 & 0.064 & 1.32 \\
\hline$T_{3}$ & 0.380 & 0.153 & $0.318^{*}$ & $49.21^{*}$ & 1.43 & 0.049 & $1.08^{*}$ \\
\hline$T_{4}$ & $0.352^{*}$ & 0.128 * & 0.309 * & $42.75^{*}$ & 1.24 * & 0.042 & 0.91 ** \\
\hline $\mathrm{T}_{5}$ & $0.310^{* *}$ & $0.109^{* *}$ & $0.301^{*}$ & $39.71^{* *}$ & 1.03 * & 0.034 * & 0.74 ** \\
\hline \multirow{2}{*}{$\begin{array}{r}\text { L.S.D } 5 \% \\
1 \%\end{array}$} & 0.139 & 0.063 & 0.096 & 14.50 & 0.46 & 0.018 & 0.33 \\
\hline & 0.181 & 0.091 & 0.128 & 21.96 & 0.75 & 0.030 & 0.51 \\
\hline
\end{tabular}

${ }^{*}$ Concentrations of $\mathrm{Pb}, \mathrm{Cd}$ and $\mathrm{Ni}$ in $\mathrm{T}_{1}$ were 500, 50 and $25 \mathrm{ppm}$, and in $\mathrm{T}_{2}, \mathrm{~T}_{3}, \mathrm{~T}_{4}$ and $\mathrm{T}_{5}$ were 2-, 3-, 4- and 5-fold of these concentrations, respectively

These results may be due to the indirect effects of heavy metals on photosystems related to the disturbances caused by the metals in Calvin cycle and downregulation or even feedback inhibition of electron transport by the excessive amounts of ATP and NADPH (Krupa et al., 1993). Droppa et al. (1996), however suggested that $\mathrm{Cd}$ in green leaves interferes with chlorophyll biosynthesis, acts mainly by inhibiting the LHC synthesis into stable complexes required for normal functional photosynthetic activity.

A progressive increase was observed in $\mathrm{Pb}, \mathrm{Cd}$ and $\mathrm{Ni}$ content (ppm) in the leaves and roots (Table, 2) with significant differences for $T_{3}$ combination and highly significant ones for both $T_{4}$ and $T_{5}$ combinations compared to control in the first period of growth, while in the second one, the level of significancy was elevated for $\mathrm{T}_{2}$ treatment in the leaves and for both $T_{1}$ and $T_{2}$ treatments in the roots to become significant. In general, the 
content of the three heavy metals in the roots was higher than in the leaves, and in the second period than in the first one. This may indicate that transportation of the used toxic metals to leaves was less than accumulation of them in the roots. However, absorption of metals by roots of plants grown in polluted soil may be necessary for keeping the equilibrium between metals concentration in soil medium and nutrients content in plant tissues (Foy et al, 1978).

Table (2): Effect of heavy metals combinations on $\mathrm{Pb}, \mathrm{Cd}$ and $\mathrm{Ni}$ content (ppm) in the leaves and roots of Acalypha wilkesiana Müll. Arg. during the two periods of growth in the second season

\begin{tabular}{|c|c|c|c|c|c|c|}
\hline \multirow[t]{2}{*}{ Treatments } & \multicolumn{3}{|c|}{$\begin{array}{c}\text { First period of growth } \\
\text { (terminal of October 2007) }\end{array}$} & \multicolumn{3}{|c|}{$\begin{array}{l}\text { Second period of growth } \\
\text { (terminal of October 2008) }\end{array}$} \\
\hline & $\mathrm{Pb}$ & $\mathrm{Cd}$ & $\mathrm{Ni}$ & $\mathrm{Pb}$ & $\mathrm{Cd}$ & $\mathrm{Ni}$ \\
\hline & \multicolumn{6}{|c|}{ In the leaves } \\
\hline Control & 3.76 & 0.50 & nil & 4.06 & 0.56 & nil \\
\hline $\mathrm{T}_{1}$ & 7.35 & 2.41 & 1.08 & 8.38 & 2.60 & 1.21 \\
\hline$T_{2}$ & 13.50 & 3.28 & 1.67 & $13.78^{*}$ & 3.74 * & 1.88 * \\
\hline$T_{3}$ & $15.77^{*}$ & $6.21^{*}$ & 1.97 & 17.03 * & $6.71^{*}$ & 2.20 * \\
\hline $\mathbf{T}_{4}$ & $23.48^{* *}$ & $8.92^{\text {** }}$ & $2.84^{\text {** }}$ & $25.21^{* *}$ & $9.58^{* *}$ & $3.19^{* *}$ \\
\hline$T_{5}$ & 30.24 ** & $10.90^{* *}$ & $3.36^{* *}$ & $32.40^{* *}$ & $11.86^{* *}$ & $3.75^{* *}$ \\
\hline \multirow{3}{*}{$\begin{array}{r}\text { L.S.D } 5 \% \\
1 \% \\
\end{array}$} & 9.76 & 2.86 & 1.98 & 9.05 & 2.31 & 1.66 \\
\hline & 16.28 & 7.42 & 2.63 & 15.97 & 6.84 & 3.01 \\
\hline & \multicolumn{6}{|c|}{ In the roots } \\
\hline Control & 6.79 & 0.78 & nil & 7.35 & 0.93 & nil \\
\hline $\mathrm{T}_{1}$ & 9.68 & 3.56 & 1.19 & 10.50 & 3.98 * & $1.97^{*}$ \\
\hline$T_{2}$ & 17.07 & 5.91 & 1.97 & $18.47^{*}$ & 6.50 * & $2.16^{*}$ \\
\hline$T_{3}$ & $21.86^{*}$ & $8.45^{*}$ & $2.63^{* *}$ & $23.55^{*}$ & 9.20 ** & 2.96 * \\
\hline $\mathbf{T}_{4}$ & $28.73^{* *}$ & $12.54^{* \star}$ & $4.70^{* *}$ & $31.10^{* *}$ & $13.67^{\text {** }}$ & $5.23^{* *}$ \\
\hline $\mathrm{T}_{5}$ & $34.10^{* *}$ & $15.82^{* *}$ & $5.23^{* *}$ & $36.78^{* *}$ & $17.33^{\text {** }}$ & $5.78^{* *}$ \\
\hline \multirow{2}{*}{$\begin{array}{r}\text { L.S.D } \begin{array}{r}5 \% \\
1 \%\end{array}\end{array}$} & 10.97 & 5.33 & 2.16 & 10.32 & 3.00 & 1.84 \\
\hline & 17.94 & 10.67 & 3.51 & 18.75 & 6.58 & 3.30 \\
\hline
\end{tabular}

* Concentrations of $\mathrm{Pb}, \mathrm{Cd}$ and $\mathrm{Ni}$ in $\mathrm{T}_{1}$ were 500, 50 and $25 \mathrm{ppm}$, and in $\mathrm{T}_{2}, \mathrm{~T}_{3}, \mathrm{~T}_{4}$ and $\mathrm{T}_{5}$ were 2-, 3-, 4- and 5-fold of these concentrations, respectively

Although the Jacob's coat transplants absorbed high amounts of $\mathrm{Pb}, \mathrm{Cd}$ and $\mathrm{Ni}$, the concentrations of such metals did not reach the upper critical levels, which ranged in various plant tissues between 50-60, 60-120 and 8-12 ppm for the three metals mentioned above, respectively (Macnicol and Beckett, 1985). However, these findings are in accordance with those attained by Shahin et al. (2002) on Salvia and Vinca; Bush et al. (2003) on Betula nigra and Ulmus parvifolia; Laypheng et al. (2004) on Bougainvillea spectabilis, Ixora coccinea and Heleconia taxa and Shahin et al. (2007) on stock and Cape marigold.

\section{Asclepias curassavica L. (Blood flower):}

Data averaged in Table (3) exhibited that the least combination of heavy metals $\left(T_{1}\right)$ caused a non-significant increase in chlorophyll $a, b$ and carotenoids contents ( $\mathrm{mg} / \mathrm{g}$ fresh weight), as well as in the percentages of total carbohydrates, N, P and $\mathrm{K}$ in the leaves during the two periods of growth, except for chlorophyll $\mathrm{b}$ content in the first growth period that was 
significantly raised, whereas higher combinations $\left(T_{2}, T_{3}, T_{4}\right.$ and $\left.T_{5}\right)$ induced a progressive decrement in these constituents as heavy metals concentrations increased. So, the least records were due to the highest level of toxic metals $\left(T_{5}\right)$. It was noticed that chlorophylls $a$ and $b$ were more affected by toxicity of heavy metals than total carbohydrates, N, P and K parameters, especially under medium levels $\left(T_{2}\right.$ and $\left.T_{3}\right)$ during the two periods of growth.

Table (3): Effect of heavy metals combinations on some chemical constituents of Asclepias curassavica L. leaves during the two periods of growth in the second season

\begin{tabular}{|c|c|c|c|c|c|c|c|}
\hline \multirow[t]{2}{*}{ Treatments } & $\begin{array}{c}\text { Chlorophyll } \\
\text { a } \\
\text { (mg/g f. w.) }\end{array}$ & $\begin{array}{c}\text { Chlorophyll } \\
\text { b } \\
\text { (mg/g f. w.) }\end{array}$ & $\begin{array}{l}\text { Carotenoids } \\
\text { (mg/g f. w.) }\end{array}$ & $\begin{array}{c}\text { Total } \\
\text { carbohydrates } \\
(\%)\end{array}$ & $\begin{array}{c}N \\
(\%)\end{array}$ & $\begin{array}{l}P \\
(\%)\end{array}$ & $\begin{array}{l}K \\
(\%)\end{array}$ \\
\hline & \multicolumn{7}{|c|}{ First period of growth (terminal of October 2007) } \\
\hline Control & 0.739 & 0.566 & 0.337 & 70.10 & 1.38 & 0.078 & 2.76 \\
\hline $\mathrm{T}_{1}$ & 0.817 & 0.658 * & 0.361 & 77.68 & 1.51 & 0.086 & 2.89 \\
\hline $\mathbf{T}_{2}$ & 0.698 & 0.505 & 0.337 & 66.23 & 1.28 & 0.076 & 2.58 \\
\hline $\mathbf{T}_{3}$ & $0.646^{*}$ & $0.456^{*}$ & 0.341 & 60.51 & 1.21 & 0.067 & 2.03 \\
\hline$T_{4}$ & 0.626 * & $0.433^{* *}$ & 0.296 & $58.33^{*}$ & $1.03^{*}$ & 0.053 & $1.81^{*}$ \\
\hline $\mathbf{T}_{5}$ & $0.538^{* *}$ & 0.326 ** & 0.250 * & 51.08 * & 0.97 * & $0.046^{*}$ & $1.62^{* *}$ \\
\hline \multirow{3}{*}{$\begin{array}{r}\text { L.S.D } 5 \% \\
1 \% \\
\end{array}$} & 0.081 & 0.076 & 0.045 & 11.33 & 0.32 & 0.026 & 0.75 \\
\hline & 0.143 & 0.114 & 0.094 & 19.18 & 0.49 & 0.037 & 1.01 \\
\hline & \multicolumn{7}{|c|}{ Second period of growth (terminal of October 2008) } \\
\hline Control & 0.723 & 0.546 & 0.326 & 66.50 & 1.31 & 0.081 & 2.63 \\
\hline $\mathrm{T}_{1}$ & 0.780 & 0.627 & 0.344 & 70.15 & 1.45 & 0.085 & 2.76 \\
\hline$T_{2}$ & 0.661 & 0.480 & 0.320 & 62.70 & 1.20 & 0.073 & 2.45 \\
\hline$T_{3}$ & $0.615^{*}$ & $0.431^{*}$ & 0.324 & 57.00 & 0.98 * & 0.061 & 1.92 \\
\hline$T_{4}$ & $0.595^{*}$ & $0.409^{* *}$ & $0.285^{*}$ & $55.43^{*}$ & 0.96 * & $0.050^{*}$ & $1.70^{*}$ \\
\hline $\mathrm{T}_{5}$ & $0.511^{* *}$ & $0.312^{* *}$ & $0.233^{*}$ & $48.53^{*}$ & 0.93 * & $0.042^{* *}$ & 1.50 * \\
\hline \multirow{2}{*}{$\begin{array}{r}\text { L.S.D } 5 \% \\
1 \%\end{array}$} & 0.097 & 0.083 & 0.039 & 10.67 & 0.30 & 0.018 & 0.33 \\
\hline & 0.148 & 0.129 & 0.087 & 18.42 & 0.46 & 0.030 & 0.51 \\
\hline
\end{tabular}

${ }^{*}$ Concentrations of $\mathrm{Pb}, \mathrm{Cd}$ and $\mathrm{Ni}$ in $\mathrm{T}_{1}$ were 500, 50 and $25 \mathrm{ppm}$, and in $\mathrm{T}_{2}, \mathrm{~T}_{3}, \mathrm{~T}_{4}$ and $\mathrm{T}_{5}$ were 2-, 3-, 4- and 5-fold of these concentrations, respectively

On the other hand, contents of $\mathrm{Pb}, \mathrm{Cd}$ and $\mathrm{Ni}(\mathrm{ppm})$ in the leaves and roots (Table, 4) were markedly increased with various significant levels in the two periods of growth. Their content in the roots was higher than that in the leaves. However, accumulation of toxic metals in plant tissues usually leads to depression of vital processes, such as photosynthesis, inhibition of some enzymatic systems and blocking the formation of proteins and chlorophylls (Mengel and Kirkby, 1979). A reduction in glutathione reductase activity in relation to Cd and Ni stress was registered by Schickler and Caspi (1999) in Alyssum argentium. Moreover, Salgare and Palathingal (2002) found that industrial pollution delayed flowering of Allamanda cathartica plants due to a reduction in cytokinin and gibberellin activities, and in sucrose and glucose contents in bud meristems during the transition to flowering. Similarly were those results pointed out by Dissanayake et al. (2002) on Lantana camara, Albizzia odoratissima and Wedelia trilobata; Rossini-Oliva and Rautio (2004) on Duranta repens and Shahin and El-Malt (2006) on sant, oak and tipu. 
Table (4): Effect of heavy metals combinations on $\mathrm{Pb}, \mathrm{Cd}$ and $\mathrm{Ni}$ content (ppm) in the leaves and roots of Asclepias curassavica $\mathrm{L}$. during the two periods of growth in the second season

\begin{tabular}{|c|c|c|c|c|c|c|}
\hline \multirow[t]{2}{*}{ Treatments } & \multicolumn{3}{|c|}{$\begin{array}{c}\text { First period of growth } \\
\text { (terminal of October 2007) }\end{array}$} & \multicolumn{3}{|c|}{$\begin{array}{l}\text { Second period of growth } \\
\text { (terminal of October 2008) }\end{array}$} \\
\hline & $\mathrm{Pb}$ & $\mathrm{Cd}$ & $\mathrm{Ni}$ & $\mathrm{Pb}$ & $\mathrm{Cd}$ & $\mathrm{Ni}$ \\
\hline & \multicolumn{6}{|c|}{ In the leaves } \\
\hline Control & 2.18 & 0.78 & nil & 2.31 & 0.84 & nil \\
\hline $\mathrm{T}_{1}$ & 4.36 & 3.96 & 1.09 & 4.78 & 4.33 & 1.18 \\
\hline$T_{2}$ & 10.90 & 7.49 & $2.27^{*}$ & $11.87^{*}$ & 8.64 & 2.49 * \\
\hline$T_{3}$ & 15.28 * & 15.26 ** & 3.10 ** & 16.76 * & 17.28 ** & 3.46 ** \\
\hline$T_{4}$ & $17.85^{\star \star}$ & $17.66^{* *}$ & $4.91^{\text {** }}$ & 19.89 ** & 19.44 ** & $5.41^{* *}$ \\
\hline $\mathrm{T}_{5}$ & 22.89 ** & 21.26 ** & 5.50 ** & $25.46^{* *}$ & $23.76^{* *}$ & $6.48^{* \star}$ \\
\hline \multirow{3}{*}{$\begin{array}{r}\text { L.S.D } 5 \% \\
1 \% \\
\end{array}$} & 8.75 & 6.83 & 1.17 & 9.10 & 7.81 & 1.33 \\
\hline & 13.62 & 11.47 & 2.36 & 14.93 & 12.40 & 2.50 \\
\hline & \multicolumn{6}{|c|}{ In the roots } \\
\hline Control & 3.70 & 1.03 & nil & 4.03 & 1.08 & nil \\
\hline $\mathrm{T}_{1}$ & 5.78 & 4.36 & $1.58^{*}$ & 6.28 & 5.19 & $1.73^{*}$ \\
\hline$T_{2}$ & $14.16^{\wedge}$ & $9.81^{*}$ & $2.96^{*}$ & $15.47^{*}$ & $10.83^{*}$ & $3.25^{* *}$ \\
\hline$T_{3}$ & 21.80 ** & $18.60^{* *}$ & $4.51^{\text {** }}$ & 23.76 ** & 20.56 ** & $4.86^{* *}$ \\
\hline$T_{4}$ & $25.07^{\star *}$ & $23.98^{* *}$ & $6.33^{* *}$ & 28.09 ** & 26.00 ** & $6.81^{* *}$ \\
\hline$T_{5}$ & $33.21^{* *}$ & $31.76^{* \star}$ & 7.29 ** & $34.67^{* *}$ & 34.56 ** & 7.90 ** \\
\hline \multirow{2}{*}{$\begin{array}{r}\text { L.S.D } \begin{array}{r}5 \% \\
1 \%\end{array}\end{array}$} & 9.64 & 7.88 & 1.34 & 10.64 & 8.35 & 1.70 \\
\hline & 14.10 & 12.35 & 3.00 & 16.73 & 13.46 & 3.16 \\
\hline
\end{tabular}
were 2-, 3-, 4- and 5-fold of these concentrations, respectively

\section{Dodonaea viscosa (L.) Jacq. (Hop bush):}

On the contrary of what was found in Acalypha and Asclepias transplants, data in Table (5) indicated that all heavy metals combinations declined the content of chlorophyll a, b, carotenoids, total carbohydrates, N, P and $\mathrm{K}$ in the leaves of hop bush transplants with significant differences in both growth periods, except for combination No. $1\left(T_{1}\right)$, which caused a slight elevation in the content of $\mathrm{K}$ in the second period only. The utmost low content in the previous constituents was generally referred to the highest rates of heavy metals ( $T_{4}$ and $\left.T_{5}\right)$.

As for the content of $\mathrm{Pb}, \mathrm{Cd}$ and $\mathrm{Ni}$ in the leaves and roots, data in Table (6) show that they were gradually raised with increasing heavy metals concentration in either periods of growth. However, the content of these metals was higher in the roots than in the leaves, and in the second growth period than in the first one indicating their continuous absorption with prolonging the growth period. Hence, the highest contents of these metals was found in the roots of transplants polluted with the highest levels of them, especially in the second period of growth.

The aforementioned results could be explained and discussed as done before in case of both Acalypha and Asclepias transplants. 
Table (5): Effect of heavy metals combinations on some chemical constituents of Dodonaea viscosa (L.) Jacq. leaves during the two periods of growth in the second season

\begin{tabular}{|c|c|c|c|c|c|c|c|}
\hline \multirow[t]{2}{*}{ Treatments } & $\begin{array}{c}\text { Chlorophyll } \\
\text { a } \\
\text { (mg/g f. w.) }\end{array}$ & $\begin{array}{c}\text { Chlorophyll } \\
\text { b } \\
\text { (mg/g f. w.) }\end{array}$ & $\begin{array}{l}\text { Carotenoids } \\
\text { (mg/g f. w.) }\end{array}$ & $\begin{array}{c}\text { Total } \\
\text { carbohydrates (\%) }\end{array}$ & $\begin{array}{c}N \\
(\%)\end{array}$ & $\begin{array}{l}P \\
(\%)\end{array}$ & $\begin{array}{c}K \\
(\%) \\
\end{array}$ \\
\hline & \multicolumn{7}{|c|}{ First period of growth (terminal of October 2007) } \\
\hline Control & 0.465 & 0.471 & 0.430 & \begin{tabular}{|c|}
58.73 \\
\end{tabular} & 1.18 & 0.047 & 1.26 \\
\hline $\mathrm{T}_{1}$ & 0.552 & 0.465 & 0.428 & 57.38 & 1.16 & 0.053 & 1.38 \\
\hline $\mathbf{T}_{2}$ & 0.461 & 0.384 & 0.400 & $47.46^{*}$ & 1.16 & 0.042 & 1.32 \\
\hline $\mathbf{T}_{3}$ & 0.430 * & $0.306^{*}$ & 0.368 & $44.07^{*}$ & 0.89 & 0.036 & 1.10 * \\
\hline $\mathbf{T}_{4}$ & $0.407^{* \star}$ & $0.276^{* \star}$ & 0.352 * & $41.78^{* *}$ & $0.82 *$ & $0.033^{*}$ & $0.91^{* *}$ \\
\hline \begin{tabular}{l|l}
$\mathbf{T}_{5}$ & \\
\end{tabular} & 0.400 ** & $0.306^{* *}$ & $0.337^{*}$ & $40.67^{* *}$ & $0.82^{*}$ & 0.030 * & 0.90 ** \\
\hline \multirow{3}{*}{$\begin{array}{r}\text { L.S.D } 5 \% \\
1 \% \\
\end{array}$} & 0.106 & 0.096 & 0.076 & 9.97 & 0.30 & 0.012 & 0.15 \\
\hline & 0.151 & 0.167 & 0.098 & \begin{tabular}{|c|}
14.86 \\
\end{tabular} & 0.39 & 0.018 & 0.24 \\
\hline & \multicolumn{7}{|c|}{ Second period of growth (terminal of October 2008) } \\
\hline Control & 0.558 & 0.483 & 0.451 & \begin{tabular}{|c|c|}
60.63 \\
\end{tabular} & 1.24 & 0.063 & 1.33 \\
\hline $\mathrm{T}_{1}$ & 0.569 & 0.488 & 0.449 & 59.85 & 1.22 & 0.056 & 1.45 \\
\hline$T_{2}$ & 0.483 & 0.396 & 0.418 & $48,93^{*}$ & 1.17 & 0.043 & 1.39 \\
\hline$T_{3}$ & 0.452 * & $0.327^{*}$ & $0.387^{*}$ & 45.21 * & $0.91 *$ & 0.035 * & 1.16 \\
\hline$T_{4}$ & $0.421^{*}$ & 0.291 ** & $0.361^{*}$ & 41.50 ** & 0.84 * & 0.031 * & $0.90^{* *}$ \\
\hline $\mathrm{T}_{5}$ & $0.403^{* *}$ & $0.263^{* *}$ & 0.354 * & $39.81^{\text {** }}$ & 0.81 * & $0.028^{*}$ & $0.83^{\text {** }}$ \\
\hline L.S.D $5 \%$ & 0.100 & 0.099 & 0.081 & 10.33 & 0.33 & 0.022 & 0.18 \\
\hline $1 \%$ & 0.139 & 0.170 & 0.103 & 16.21 & 0.45 & 0.033 & 0.31 \\
\hline
\end{tabular}

${ }^{*}$ Concentrations of $\mathrm{Pb}, \mathrm{Cd}$ and $\mathrm{Ni}$ in $\mathrm{T}_{1}$ were 500, 50 and $25 \mathrm{ppm}$, and in $\mathrm{T}_{2}, \mathrm{~T}_{3}, \mathrm{~T}_{4}$ and $\mathrm{T}_{5}$ were 2-, 3-, 4- and 5-fold of these concentrations, respectively

Table (6): Effect of heavy metals combinations on $\mathrm{Pb}, \mathrm{Cd}$ and $\mathrm{Ni}$ content (ppm) in the leaves and roots of Dodonaea viscosa (L.) Jacq. during the two periods of growth in the second season

\begin{tabular}{|c|c|c|c|c|c|c|}
\hline \multirow[t]{2}{*}{ Treatments } & \multicolumn{3}{|c|}{$\begin{array}{c}\text { First period of growth } \\
\text { (terminal of October 2007) }\end{array}$} & \multicolumn{3}{|c|}{$\begin{array}{l}\text { Second period of growth } \\
\text { (terminal of October 2008) }\end{array}$} \\
\hline & $\mathrm{Pb}$ & $\mathrm{Cd}$ & $\mathbf{N i}$ & $\mathrm{Pb}$ & $\mathrm{Cd}$ & $\mathrm{Ni}$ \\
\hline & \multicolumn{6}{|c|}{ In the leaves } \\
\hline Control & 1.12 & 0.53 & nil & 1.21 & 0.63 & nil \\
\hline $\mathrm{T}_{1}$ & 2.28 & 1.20 & 0.60 * & 2.65 & 1.50 & 0.71 * \\
\hline$T_{2}$ & 4.39 * & $2.16^{*}$ & $0.98^{*}$ & $5.18^{*}$ & $2.63^{* *}$ & $1.15^{* *}$ \\
\hline$T_{3}$ & 5.26 * & $4.15^{* *}$ & 2.40 ** & $6.93^{* *}$ & 4.76 ** & 2.88 ** \\
\hline$T_{4}$ & $9.27^{* *}$ & 5.98 ** & $3.31^{* \star}$ & 11.04 ** & $6.98^{* *}$ & $3.91^{\text {** }}$ \\
\hline$T_{5}$ & $13.85^{* *}$ & $6.54^{* *}$ & 4.06 ** & $16.10^{* *}$ & $8.07^{* *}$ & $5.07^{* *}$ \\
\hline \multirow{3}{*}{$\begin{array}{r}\text { L.S.D } 5 \% \\
1 \% \\
\end{array}$} & 2.67 & 0.76 & 0.46 & 2.47 & 0.88 & 0.50 \\
\hline & 5.10 & 1.68 & 0.69 & 4.16 & 1.93 & 0.78 \\
\hline & \multicolumn{6}{|c|}{ In the roots } \\
\hline Control & 2.60 & 0.78 & nil & 2.88 & 0.87 & nil \\
\hline $\mathrm{T}_{1}$ & 3.99 & $2.19 *$ & 0.83 * & 4.67 & $2.53^{*}$ & $1.04^{* *}$ \\
\hline$T_{2}$ & 5.67 & $3.42^{* *}$ & $1.25^{* *}$ & $6.71^{*}$ & $4.03^{* *}$ & 1.50 * \\
\hline$T_{3}$ & $7.63^{*}$ & 4.96 ** & $3.57^{* *}$ & $8.98^{* *}$ & $5.87^{\text {** }}$ & $4.15^{\text {**}}$ \\
\hline$T_{4}$ & $10.48^{* *}$ & $6.86^{\star *}$ & 5.02 ** & 12.20 ** & 8.10 ** & $6.33^{\text {** }}$ \\
\hline $\mathrm{T}_{5}$ & 15.29 ** & $8.18^{* *}$ & 6.49 ** & $17.83^{* *}$ & $9.78^{* *}$ & $7.71^{\text {** }}$ \\
\hline \multirow{2}{*}{$\begin{array}{r}\text { L.S.D } 5 \% \\
1 \%\end{array}$} & 3.26 & 1.08 & 0.71 & 2.80 & 0.97 & 0.77 \\
\hline & 6.84 & 2.17 & 0.95 & 5.13 & 2.38 & 1.02 \\
\hline
\end{tabular}

Concentrations of $\mathrm{Pb}, \mathrm{Cd}$ and $\mathrm{Ni}$ in $\mathrm{T}_{1}$ were 500,50 and $25 \mathrm{ppm}$, and in $\mathrm{T}_{2}, \mathrm{~T}_{3}, \mathrm{~T}_{4}$ and $\mathrm{T}_{5}$ were 2-, 3-, 4- and 5-fold of these concentrations, respectively 


\section{Tabernaemontana divaricata (L.) R. Br. ex Roem\& Schult. (Crepe} jasmine or Crepe gardenia):

It is obvious from data in Table (7) that chlorophyll a, b and carotenoids content ( $\mathrm{mg} / \mathrm{g}$ fresh weight), as well as the percentages of total carbohydrates, N, P and $\mathrm{K}$ in the leaves were augmentatively depressed as a result of raising the rates of heavy metals in polluted soil with significant and highly-significant differences in the most cases of the two growth periods, except for $\mathrm{T}_{1}$ combination, which slightly improved the contents of chlorophyll $\mathrm{b}$, carotenoids and nitrogen compared to those of transplants grown in unpolluted soil.

With regard to heavy metals content (ppm) in the leaves and roots, data recorded in Table (8) revealed that $\mathrm{Cd}$ and $\mathrm{Ni}$ were significantly increased in response to $T_{1}$ treatment during the two growth periods, while other treatments $\left(T_{2}, T_{3}, T_{4}\right.$ and $\left.T_{5}\right)$ greatly elevated the content of the three metals with highly significant differences in both periods of growth. Such gains, however may be interpreted and discussed as previously mentioned in case of both Acalypha and Asclepias transplants.

Table (7): Effect of heavy metals combinations on some chemical constituents of Tabernaemontana divaricata (L.) $\mathrm{R}$. Br. ex Roem\& Schult. leaves during the two periods of growth in the second season

\begin{tabular}{|c|c|c|c|c|c|c|c|}
\hline \multirow[t]{2}{*}{ Treatments } & $\begin{array}{c}\text { Chlorophyll } \\
\text { a } \\
\text { (mg/g f. w.) }\end{array}$ & $\begin{array}{l}\text { Chlorophyll } \\
\text { b } \\
\text { (mg/g f. w.) }\end{array}$ & $\begin{array}{l}\text { Carotenoids } \\
\text { (mg/g f. w.) }\end{array}$ & $\begin{array}{c}\text { Total } \\
\text { carbohydrates } \\
(\%)\end{array}$ & $\begin{array}{c}N \\
(\%)\end{array}$ & $\begin{array}{l}P \\
(\%)\end{array}$ & $\begin{array}{l}K \\
(\%)\end{array}$ \\
\hline & \multicolumn{7}{|c|}{ First period of growth (terminal of October 2007) } \\
\hline Control & 0.578 & 0.433 & 0.375 & 74.39 & 2.80 & 0.134 & 2.25 \\
\hline $\mathrm{T}_{1}$ & 0.529 & 0.456 & 0.382 & 67.98 & 2.96 & 0.121 & 2.03 \\
\hline $\mathbf{T}_{2}$ & 0.478 & $0.271^{*}$ & 0.366 & $61.57^{*}$ & 2.35 & 0.110 & $1.83^{*}$ \\
\hline $\mathbf{T}_{3}$ & 0.359 ** & 0.268 * & 0.357 & $58.18^{*}$ & $1.87^{*}$ & $0.083^{*}$ & 1.80 * \\
\hline $\mathbf{T}_{4}$ & $0.361^{* *}$ & $0.221^{* *}$ & $0.284^{*}$ & $46.23^{* *}$ & $1.72^{* *}$ & $0.081^{*}$ & $1.64^{* *}$ \\
\hline \begin{tabular}{l|l}
$T_{5}$ \\
\end{tabular} & $0.231^{* *}$ & $0.180^{* *}$ & 0.269 * & $39.56^{* *}$ & $1.17^{* *}$ & $0.057^{* *}$ & $1.43^{* *}$ \\
\hline \multirow{3}{*}{$\begin{array}{rr}\text { L.S.D } 5 \% \\
1 \% \\
\end{array}$} & 0.109 & 0.160 & 0.072 & 10.76 & 0.48 & 0.051 & 0.40 \\
\hline & 0.210 & 0.207 & 0.094 & 16.38 & 0.95 & 0.070 & 0.60 \\
\hline & \multicolumn{7}{|c|}{ Second period of growth (terminal of October 2008) } \\
\hline Control & 0.549 & 0.421 & 0.395 & 70.30 & 2.67 & 0.117 & 2.13 \\
\hline $\mathrm{T}_{1}$ & 0.512 & 0.433 & 0.406 & 65.61 & 2.81 & 0.114 & 1.93 \\
\hline$T_{2}$ & 0.458 & 0.319 & 0.384 & 58.90 & 2.17 & 0.103 & 1.74 \\
\hline$T_{3}$ & $0.346^{* *}$ & $0.276^{*}$ & 0.371 & $55.10^{*}$ & $1.88^{*}$ & $0.081^{*}$ & 1.70 * \\
\hline$T_{4}$ & $0.352^{* *}$ & $0.251^{*}$ & $0.294^{*}$ & $47.51^{\text {** }}$ & $1.65^{\text {** }}$ & 0.079 * & 1.52 * \\
\hline $\mathrm{T}_{5}$ & $0.285^{* *}$ & $0.209^{* *}$ & $0.281^{*}$ & 41.90 ** & $1.14^{* *}$ & 0.062 ** & 1.30 * \\
\hline L.S.D $5 \%$ & 0.097 & 0.109 & 0.097 & 11.50 & 0.59 & 0.033 & 0.40 \\
\hline $1 \%$ & 0.174 & 0.185 & 0.141 & 17.79 & 0.88 & 0.052 & 0.67 \\
\hline
\end{tabular}


Table (8): Effect of heavy metals combinations on $\mathrm{Pb}, \mathrm{Cd}$ and $\mathrm{Ni}$ content (ppm) in the leaves and roots of Tabernaemontana divaricata (L.) R. Br. ex Roem\& Schult. during the two periods of growth in the second season

\begin{tabular}{|c|c|c|c|c|c|c|}
\hline \multirow[t]{2}{*}{ Treatments } & \multicolumn{3}{|c|}{$\begin{array}{c}\text { First period of growth } \\
\text { (terminal of October 2007) }\end{array}$} & \multicolumn{3}{|c|}{$\begin{array}{c}\text { Second period of growth } \\
\text { (terminal of October 2008) }\end{array}$} \\
\hline & $\mathrm{Pb}$ & $\mathrm{Cd}$ & $\mathrm{Ni}$ & $\mathrm{Pb}$ & $\mathrm{Cd}$ & $\mathrm{Ni}$ \\
\hline & \multicolumn{6}{|c|}{ In the leaves } \\
\hline Control & 1.86 & 0.69 & nil & 2.03 & 0.78 & nil \\
\hline $\mathrm{T}_{1}$ & 3.81 & $1.97^{*}$ & $0.98^{*}$ & 4.20 & $2.20^{*}$ & $1.09 *$ \\
\hline $\mathrm{T}_{2}$ & $7.45^{*}$ & $3.88^{* *}$ & $2.03^{* *}$ & $8.27^{* *}$ & 4.29 ** & 2.40 ** \\
\hline$T_{3}$ & $9.86^{* *}$ & $9.54^{* *}$ & $2.80^{* *}$ & $10.88^{* *}$ & $10.46^{* *}$ & $3.28^{* *}$ \\
\hline $\mathbf{T}_{4}$ & $12.60^{* *}$ & $10.33^{* *}$ & $4.43^{* *}$ & $13.96^{* *}$ & $11.33^{* *}$ & $5.00^{* *}$ \\
\hline$T_{5}$ & $16.10^{* *}$ & $13.68^{* *}$ & 5,12 ** & $17.58^{* *}$ & $15.20^{* *}$ & $5.63^{* *}$ \\
\hline \multirow{3}{*}{$\begin{array}{r}\text { L.S.D } 5 \% \\
1 \% \\
\end{array}$} & 2.06 & 0.88 & 0.77 & 2.21 & 0.90 & 0.81 \\
\hline & 5.70 & 2.19 & 0.99 & 4.94 & 2.76 & 1.10 \\
\hline & \multicolumn{6}{|c|}{ In the roots } \\
\hline Control & 3.15 & 1.00 & nil & 3.40 & 1.10 & nil \\
\hline $\mathrm{T}_{1}$ & 5.10 & $2.78^{*}$ & $1.43^{*}$ & 5.61 & $3.10^{*}$ & $1.57^{*}$ \\
\hline$T_{2}$ & $9.54^{* *}$ & $6.84^{* *}$ & $2.68^{* *}$ & 10.50 ** & $7.67^{* *}$ & 3.00 ** \\
\hline$T_{3}$ & $12.78^{* *}$ & $10.93^{* *}$ & $4.02^{* *}$ & $14.03^{* *}$ & 12.00 ** & $4.43^{* *}$ \\
\hline $\mathbf{T}_{4}$ & $15.62^{* *}$ & $16.20^{* *}$ & $5.76^{* \star}$ & $16.51^{* *}$ & 17.98 ** & $6.40^{* *}$ \\
\hline $\mathrm{T}_{5}$ & $20.38^{* \star}$ & $21.07^{* *}$ & $6.48^{* *}$ & 22.00 ** & $23.70^{* *}$ & 7.36 ** \\
\hline \multirow{2}{*}{$\begin{array}{r}\text { L.S.D } 5 \% \\
1 \%\end{array}$} & 2.13 & 1.06 & 0.93 & 2.38 & 0.97 & 0.98 \\
\hline & 6.10 & 3.00 & 1.56 & 5.10 & 3.28 & 1.33 \\
\hline
\end{tabular}

Concentrations of $\mathrm{Pb}, \mathrm{Cd}$ and $\mathrm{Ni}$ in $\mathrm{T}_{1}$ were 500, 50 and $25 \mathrm{ppm}$, and in $\mathrm{T}_{2}, \mathrm{~T}_{3}, \mathrm{~T}_{4}$ and $\mathrm{T}_{5}$ were 2-, 3-, 4- and 5-fold of these concentrations, respectively

According to the previously stated results, it could be concluded that Acalypha wilkesiana and Asclepias curassavica transplants are considered hyper accumulators for $\mathrm{Pb}, \mathrm{Cd}$ and $\mathrm{Ni}$ toxic metals, as they absorbed more amounts of them, followed by Tabernaemontana divaricata, that absorbed medium amounts, and then Dodonaea viscose, which absorbed the least amounts.

\section{REFERENCES}

Abbaas, M. M. (2002). Effect of some heavy metals in the irrigation water on growth and chemical constituents of some timber trees. Ph. D. Thesis, Fac. Agric., Cairo Univ.

Bailey, L. H. (1976). Hortus Third. Macmillan publishing Co., Inc., 866 Third Avenue, New York, N. Y. 10022, 1290 pp.

Bush, E.; A. Owings and K. Leader (2003). Foliar accumulation of zinc in tree species grown in hardwood bark media amended with crumb rubber. J. Plant Nutrition, 26 (7): 1413-25.

Dissanayake, U. S.; K. U. Tennakoon and N. Pryantha (2002). Potential of two invasive plant species, Lantana camara L. and Wedelia trilobata L., for selective heavy metal uptake. Ceylon J. Bio. Sci., 29 (1): 1-11.

Droppa, M.; A. Oravecz; B. Boddi and G. Horvath (1996). Heavy metals inhibition of photosynthetic membrane. Proc. $1^{\text {st }}$ Egypt-Hung. Hort Conf.,Hort. Dept. Fac. Agric., Kafr El-Sheikh, 1: 13-18.

Foy, C. D.; R. L. Chaney and M. C. White (1978). The physiology of metal toxicity in plants. Ann. Rev. Plant Physiology, 29: 511-566. 
Herbert, D.; P. J. Philips and R. E. Strange (1971). Determination of total carbohydrates. Methods in Microbiology, 5 (8): 290-344.

Jackson, M. L. (1973). Soil Chemical Analysis. Prentice-Hall of India Private Ltd. M-97m New Delhi, India, 498 pp.

Krupa, Z.; A. Siedlecka; W. Maksymiec and T. Baszynski (1993). In vivo response of photosynthetic apparatus of Phaseolus vulgaris $\mathrm{L}$. to nickel toxicity. J. Plant Physiol., 142 (6): 664-668.

Laypheng, T.; H. Jie and L. Singkong (2004). Growth of some tropical ornamental plants on artificial topsoil derived from mixtures of fly ash, sludge, biochips and rengam series subsoil. J. Plant Nutrition, 27 (1): 75-94.

Luatanab, F. S. and S. R. Olsen (1965). Test of an ascorbic acid method for determining phosphorus in water and $\mathrm{NaHCO}_{3}$. extracts from soil. Soil Sci. Soc. Amer. Proc., 29: 677-678

Macnicol, R. D. and P. H. T. Beckett (1985). Critical tissue concentrations of potentially toxic elements. Plant and Soil, 85: 107-129.

Mead, R.; R. N. Curnow and A. M. Harted (1993). Statistical Methods in Agriculture and Experimental Biology, $2^{\text {nd }}$ Ed., Chapman \& Hall Ltd., London, $335 \mathrm{pp}$.

Mengel, K. and E. A. Kirkby (1979). Principles of Plant Nutrition. $2^{\text {nd }}$ Ed., International Potash Inst., P. O. Box CH-3048 Worblaufen, Bern, Switzerland, $593 \mathrm{pp}$.

Moran, R. (1982). Formula for determination of pigments extracted with $\mathrm{N}, \mathrm{N}$ dimethyl formamide. Plant Physiology, 69: 1376-81.

Pregl, F. (1945). Quantitative Organic Micro-Analysis, $4^{\text {th }}$ Ed., J. and A. Churchill Ltd., London, p. 203-209.

Rossini-Oliva, S. and P. Rautio (2004). Could ornamental plants serve as passive biomonitors in urban area?. J. Atmospheric Chemistry, 49 (1/3): 137-148.

Salgare, S. A. and T. Palathingal (2002). Effect of industrial pollution at Sewri-Mumbai. II. Changes in resting period of pollen of successive flowers of Allamanda cathartica L. Advances in Plant Science, 15 (2): 645-647.

Schickler, H. and H. Caspi (1999). Response of antioxidative enzymes to nickel and cadmium stress in hyperaccumulator plants of genus Alyssum. Physiologia Plantarum, 105 (1): 39-44..

Shahin, S. M. and A. El-Malt, Azza (2006). A study on usage of sant, oak and tipu trees for arboriculture of a polluted sandy soil. Egypt. J. Appl. Sci., 21 (7): 192-214.

Shahin, S. M.; A. M. A. Mahmoud and A. H. El-Feky (2007). How far stock and Cape marigold plants can tolerate toxicity of some heavy metals combinations?. J. Bio. Chem. Environ. Sci., 2 (2): 415-433.

Shahin, S. M.; M. H. El-Shakhs and M. H. Abdel-Salam (2002). Impact of Pb, $\mathrm{Cd}$ and $\mathrm{Hg}$ combinations on growth, flowering and chemical composition of Salvia splendens L. and Vinca rosea L. Proc. $2^{\text {nd }}$ Inter. Conf. Hort. Sci., 10-12 Sept., Kafr El-Sheikh, Tanta Univ.: 911-920. 
تأثثير الإجهاد طويل المدى بتوليفات من بعض المعادن الثقيلة على النمـو والتركيب

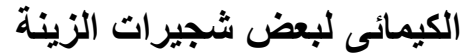

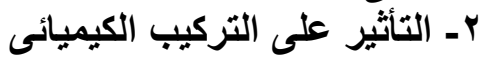

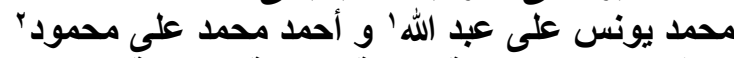

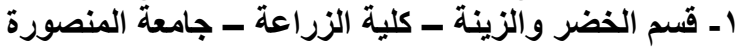

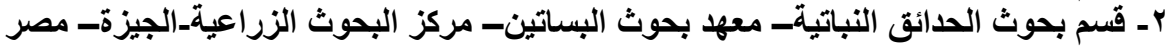

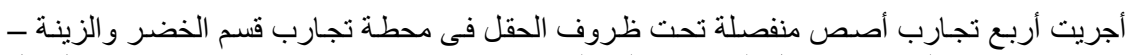

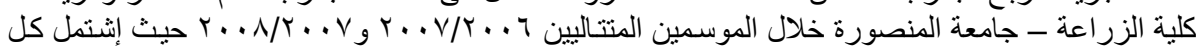

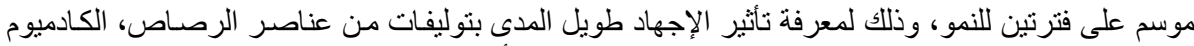

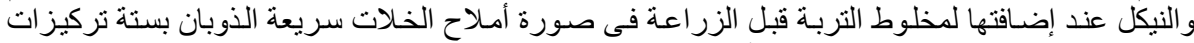

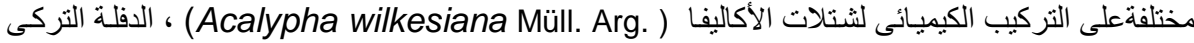

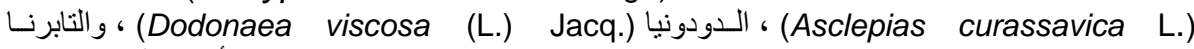
عمر ستة أثــهر المنزر عـة في (Tabernaemontana divarucata (L.) R. Br. ex Roem \& Schult.)

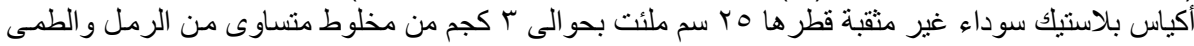

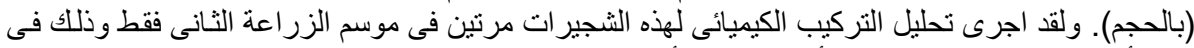

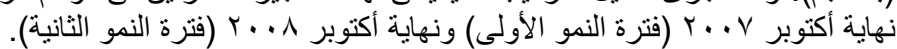

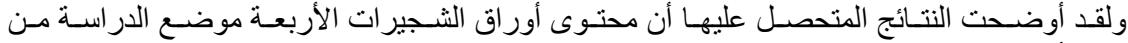

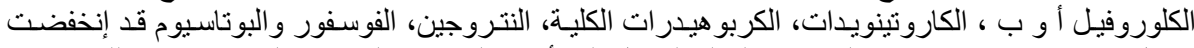

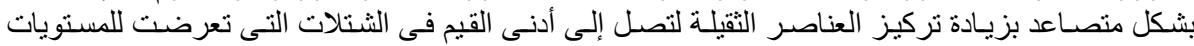

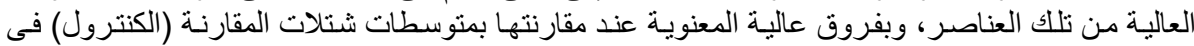

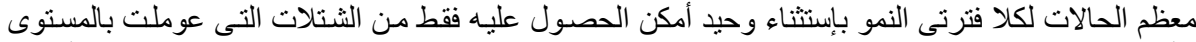

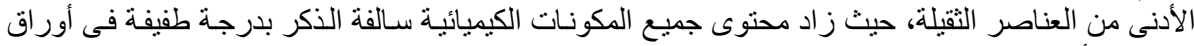

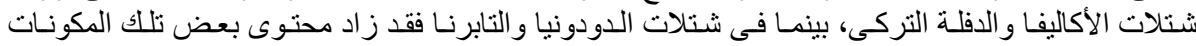

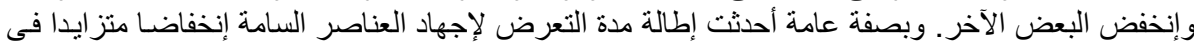

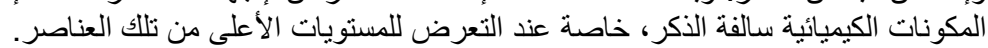

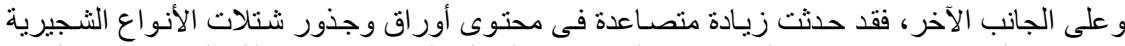

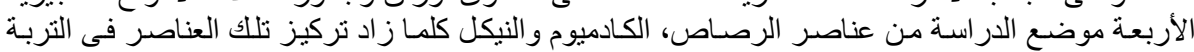

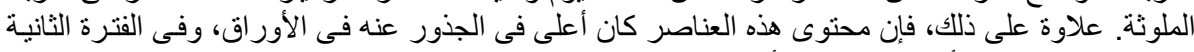

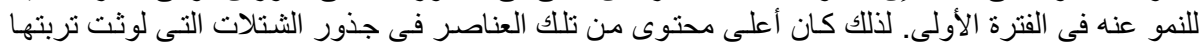

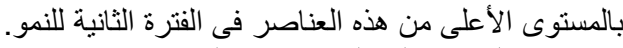

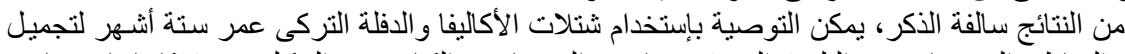

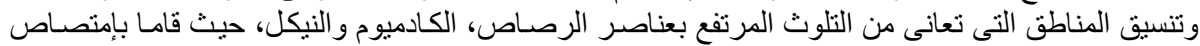

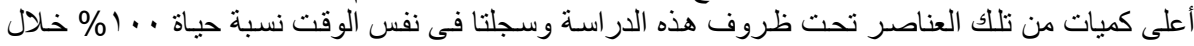
مرحلتى النمو لكلا الموسمين، تليهما التابرنا ثم الدودونيا. 
Abdalla, M. Y. A. and A. M. A. Mahmoud 